\title{
Preparation of Anti- $\alpha_{2}-$ Macroglobulin Using Canavalia lineata DC Lectin for Differentiating Species-Specificity of Blood Stains
}

\author{
Mineo Iwasa and Kaoru Sagisaka \\ Department of Legal Medicine, Gifu University School of \\ Medicine, Gifu 500
}

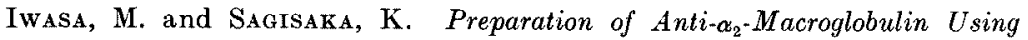
Canavalia lineata DC Lectin for Differentiating Species-Specificity of Blood Stains. Tohoku J. exp. Med., 1979, 127 (3), 209-215 — To differentiate species-specificity of blood stains, anti- $\boldsymbol{\alpha}_{2}$-macroglobulin was raised in rabbits against Canavalia lineata DC lectin-serum complex (LSC). Adsorption of anti-LSC with human lipoprotein resulted in antiserum specific for $\alpha_{2}$-macroglobulin. It was confirmed by Ouchterlony test that the antiserum adsorbed successively with monkey serum or anti-LSC adsorbed directly with monkey serum reacted with only human serum but not with mammalian ones. Immunoelectrosyneresis and anti-LSC consumption test could identify species-specificity of blood stains kept for up to two years and for up to several years, respectively. It is indicated that anti-LSC is quite effective for differentiating species-specificity of blood stains. human-specificity; serum protein; lectin
\end{abstract}

It has been one of most important problems in forensic science to determine whether or not the blood group of blood stains found on clothes of the suspected person accords with that of the victim. Recently, blood grouping has progressed remarkably by adopting the adsorption-elution method or the group-specific double combination method (the mixed agglutination method). On the other hand, ABO blood group activity has been widely detected on animals and plants. It brings us an imperative necessity to identify strictly the species-specificity of blood stains. In many cases, the identification is performed by immunoassay with anti-human hemoglobin. Judging from the similarity of chemical structure between human and mammalian hemoglobins as pointed out by Zuckerkandl (1965), the strict specification of hemoglobin might be impossible. More recently, human specificity has been investigated on plasma proteins, albumin (Bauer 1974), $\alpha_{2}$-macroglobulin (James 1965; Tsugawa et al. 1971), and $\gamma$-globulin (Dray 1960; Novotny and Franek 1972; Sivaram et al. 1975; Gibson 1977). Tsugawa et al. (1971) reported that the activity of anti-human $\alpha_{2}$-macroglobulin was not abolished by adsorption with chimpanzee serum. This result indicates that human $\alpha_{2}-$ macroglobulin has high species-specificity as compared with the other plasma proteins. Nakamura et al. (1960), investigating precipitin activity of various lectins by crossed paper electrophoresis, revealed that jack bean lectin reacted

Received for publication, May 23, 1978. 
with human serum proteins, $\alpha_{1^{-}}, \alpha_{2^{-}}$, and $\gamma$-globulins. The $\alpha_{2^{-}}$globulin was proved to be $\alpha_{2}$-macroglobulin by Harris and Robson (1963). In this paper, a preparation method of anti- $\alpha_{2}$-macroglobulin using Canavalia lineata DC lectin, which is available for investigating the species-specificity of blood stain, is described.

\section{Materials and Methods}

Preparation of $C$. lineata lectin. C. lineata lectin was pulverized with a coffee mill. The powder was mixed with tenfold volumes of saline and stirred on a magnetic stirrer. After centrifugation at $3,000 \mathrm{rpm}$ for $20 \mathrm{~min}$, the extract was defatted with one-fifth volume of ethyl ether, and the residual ethyl ether was evaporated in vacuo. Tannic acid content in the lectin was assayed by the method of Willemot and Parry (1970). The tannic acid was precipitated by adding the optimal quantity of polyethyleneglycol (molecular weight 6,000 ), and the resulting precipitate was removed by centrifugation at 10,000 rpm for $30 \mathrm{~min}$.

Preparation of lectin-serum complex $(L S C)$. The tannic acid free-lectin reacted with pooled human serum on Ouchterlony plates. Precipitation lines on the plates were cut off and washed exhaustively with saline. LSC was homogenated with a Potter's homogenizer. Simultaneously, the lectin and pooled serum were reacted in a tube at the optimal proportion. LSC was washed with saline several times.

Immunization of rabbit with LSC. Three rabbits were fortnightly given intramuscular injections of the immunogen, the mixture of $0.5 \mathrm{ml}$ of the agar homogenate and the same volume of Freund's complete adjuvant. The immunization was performed twice with and five times without the adjuvant. One week after the last injection, the rabbits were bled. The similar immunization with LSC from the tube method ( $0.2 \mathrm{ml}$ per an injection) was performed on two rabbits.

Blood stain. Blood was dropped on filter papers (Toyo Roshi Co., type No. 2) and kept at room temperature $\left(0-34^{\circ} \mathrm{C}\right)$.

Anti- $\alpha_{2}-$ macroglobulin. Anti- $\alpha_{2}-$ macroglobulin was purchased from Behringwerke (West Germany).

Lipoprotein and $\alpha_{2}$-macroglobulin. Lipoprotein was isolated from pooled serum by hydroxylapatite chromatography (Hjerten 1959). Isolation of $\alpha_{2}$-macroglobulin was performed by the method of Saunders et al. (1971).

Immunoelectrophoresis, immunoelectrosyneresis and Ouctherlony methods. Immunoelectrophoresis and syneresis with $1.2 \%$ agar-agarose $(1: 1)$ were performed using veronal buffer containing calcium lactate described by Hirshfeld (1960). Ouchterlony method was carried out with $1 \%$ agar in saline.

Anti-LSC consumption test. O group red cells were fixed with formalin according to Cox and Vermillon (1956) and treated with tannic acid by the method of Stavistky (1954). The tanned cells were coated with $\alpha_{2}$-macroglobulin. Two drops of anti-LSC, of which titer for the cells coated with $\alpha_{2}$-macroglobulin was adjusted to $1: 4$, were applied on blood stain $\left(0.2 \mathrm{~cm}^{2}\right.$ in size). After incubation for $2 \mathrm{hr}$, the antibody activity of supernatant was examined with the tanned cells on a microtitrating plate.

\section{RESULTS}

Precipitation with crude lectin. For immunoelectrosyneresis, three wells among the line of electric current were cut on an agar-agarose plate. The central well was placed with lectin, and the cathodal and anodal wells with serum. When adopting crude lectin, precipitation lines were observed both between central 
well and anodal, and between central and cathodal. Tannic acid of lectin could be removed sufficiently by adding $0.07 \mathrm{mg}$ polyethyleneglycol to $1 \mathrm{ml}$ crude lectin. The tannic acid free-lectin produced a line only between central and cathodal (Fig. 1).

Immunoelectrophoresis of serum and lectin with anti-LSC. As shown in Fig. 2, anti-LSC produced a clear line against lectin at cathodal area. At the reaction with serum, a potent line at $\alpha_{2}$-globulin area (S1), a long fine line (S2) extending to cathode and a faint line at the origin were observed. Of those lines, only S2 was clearly stained with Oil Red 0 .

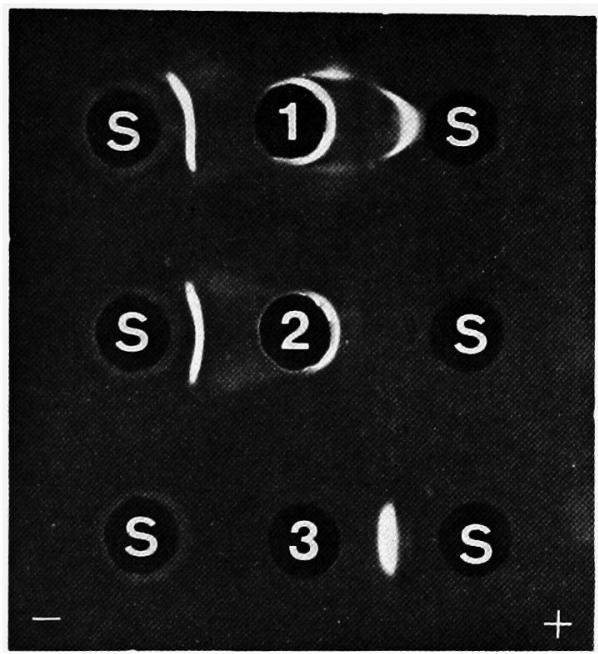

Fig. 1. Immunoelectrosyneresis of human serum with crude lectin of tannic acid free-lectin. $\mathrm{S}$; serum, 1 ; crude lectin, 2 ; tannic acid free-lectin, 3 ; tannic acid $(0.5 \mathrm{mg} / \mathrm{ml})$.

The precipitation lines between central and cathodal well due to tannic acid were observed at the reaction with crude lectin or with tannic acid.

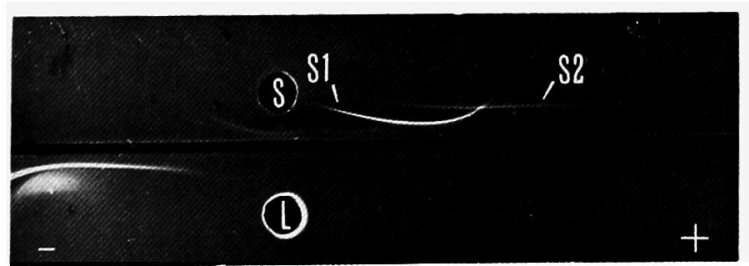

Fig. 2. Immunoelectrophoresis of lectin and serum with crude anti-LSC.

$\mathrm{S}$; serum, L; lectin.

Anti-LSC produced several precipitation lines against serum. Only precipitation line

(S2) was stained with Oil red 0.

Adsorption of crude anti-LSC with lipoprotein and animal serum. As shown in Fig. 3, it was indicated by adsorption experiments that anti-LSC adsorbed with lipoprotein $\left(5 \mathrm{mg} / \mathrm{ml}\right.$ ) at ratio $1: 0.5$ gave a line at $\alpha_{2}$-globulin region on immunoelectrophoresis. Moreover, the precipitaion line developed by the antiserum 
fused with that by monospecific antiserum to $\alpha_{2}$-macroglobulin on the Ouchterlony plate (Fig. 4).

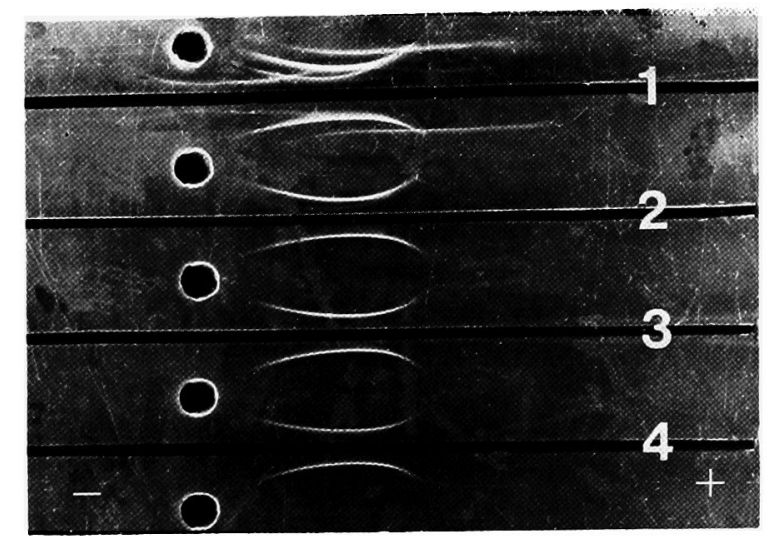

Fig. 3. Immunoelectrophoresis of serum with anti-LSC adsorbed with lipoprotein $(5 \mathrm{mg} / \mathrm{ml})$ at various ratios.

Trough 1; unadsorbed anti-LSC, 2 ; adsorbed at $1: 0.25,3$; adsorbed at 1:0.5, 4; adsorbed $1: 1$.

When adsorbed with lipoprotein at $1: 0.5$ or more, monospecific antiserum was prepared.

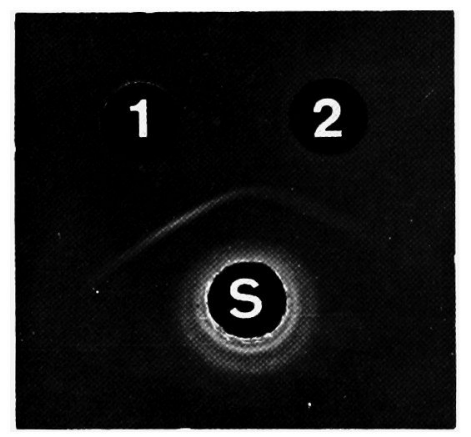

Fig. 4. Ouchterlony test of adsorbed anti-LSC and anti- $\boldsymbol{\alpha}_{2}$-macroglobulin (Wehringwerke). Well S; serum, 2; adsorbed anti-LSC, 1; anti- $\alpha_{2}$-macroglobulin. Note complete fusion of two percipitation lines.

Investigation of various animal sera with anti-LSC. As shown in Fig. 5-a, crude anti-LSC reacted distinctly with human, monkey (Macaca fuscata) and pig sera and slightly with the other animal sera examined. All animal sera except for fox produced two lines. Using anti-LSC adsorbed with lipoprotein, a potent line with human and monkey serum and a faint one with the other animals were still observed. When adsorbed repeatedly with monkey serum at the ratio of 1:0.1, the resulting antiserum was proved to react only with human serum (Fig. 5-b). For practical use, adsorption of anti-LSC only with monkey serum at the ratio of 1:0.2 produced easily the antiserum specific for human $\alpha_{2}$-macroglobulin.

Examination of human blood stain. The well of immunoelectrosyneresis was applied with blood stains $\left(0.1 \mathrm{~cm}^{2}\right)$ and filled with saline. After standing for 5 


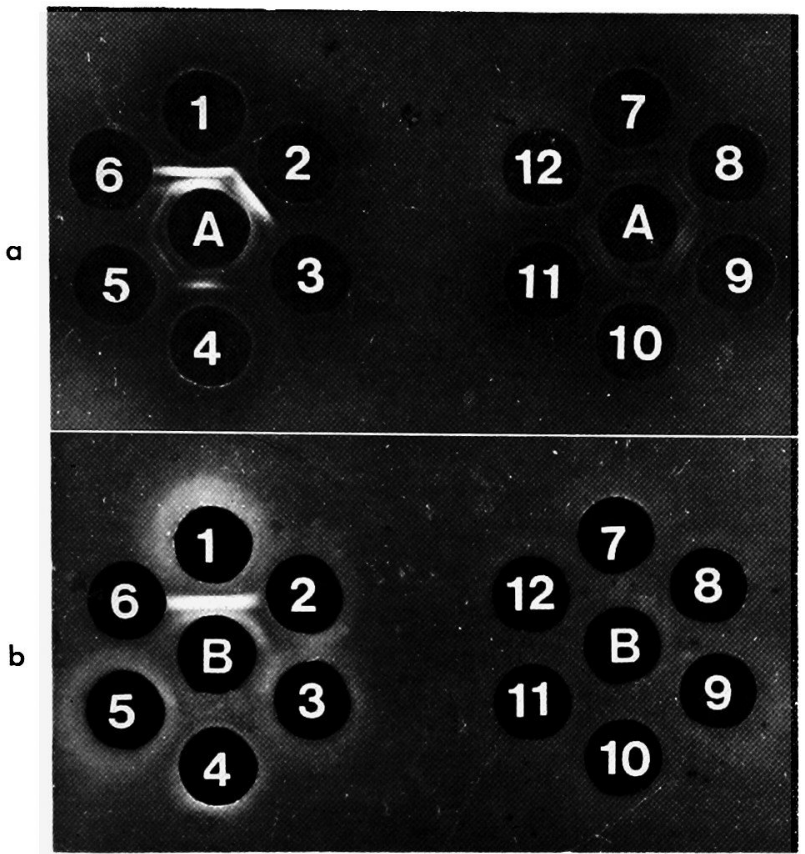

Fig. 5-a, -b. Ouchterlony test of various animal sera with anti-LSC.

Well 1; human serum, 2 ; monkey, 3 ; bovine, 4 ; pig, 5 ; dog, 6; cat, 7 ; badger, 8 ; guinea pig, 9 ; horse, 10 ; fox, 11 ; goat, 12 ; pigeon. Well A; curde anti-LSC, B; anti-LSC adsorbed with monkey serum.

Crude anti-LSC produced 2-5 precipitation lines against each animal serum. When adsorbed with monkey serum at a ratio $1: 0.2$, the antiserum reacted only with human serum.

Fig. 6. Immunoelectrosyneresis of old blood stain with anti-LSC adsorbed with monkey serum. Well 1; human serum, 2; human blood stain aged 1 year, 3 ; human blood stain aged 1.5 year, 4 ; fresh blood stain of monkey.

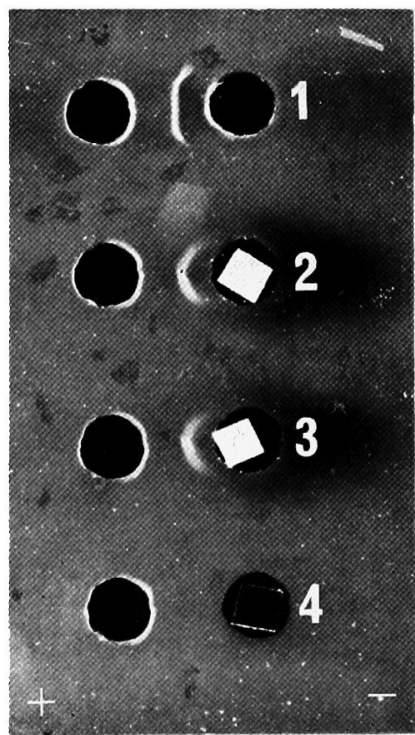


min, the stain was examined with anti-LSC adsrobed with monkey serum. Blood stains kept for about 2 years gave clear positive reaction (Fig. 6). The stains kept for about several years could be identified by the anti-LSC consumption test.

\section{Discussion}

As the techniques of blood grouping of blood or body fluid stains have remarkably progressed, strict species-identification of the stains is required of forensic scientists. In practice, it is not easy to prepare anti-human hemoglobin of high titer for the identification. Adsorption of anti-human hemoglobin with monkey hemoglobin abolished almost all precipitin activity of the antiserum. It suggests difficulty in differentiating hemoglobin of the human from that of monkey with anti-human hemoglobin. Recently, species-specificity of various plasma proteins and cell or tissue constituents has been studied. James (1965) investigated antigenic structure of $\alpha_{2}$-macroglobulin of the human, which was shown to be different from that of monkey. This evidence was supported by Tsugawa et al. (1971), who immunized rabbits with human lipoprotein of a commerical source. In this experiment, $\alpha_{2}$-macroglobulin contaminating the immunogen produced potent precipitin. Moreover, the precipitin activity was not affected by adsorption with chimpanzee serum. To differentiate human serum from monkey one by immunoassay, Gempel et al. (1960), Dray (1960) and Kuwata and Ishimoto (1976) immunized monkey with human serum. The resulting antiserum contained some precipitins to human serum proteins in each experiment. However, monkey anti-human serum prepared in our laboratory had relatively low precipitin activity. Mokashi and Madiwale (1974) demonstrated that isoenzyme patterns of peroxidase and lactate and malate dehydrogenases were useful for the differentiation between human and monkey blood. It is considered, however, that the enzyme activities are generally heatlabile and that investigation of the zymogram is laborious as routine works in forensic practice.

Blood stains kept at room temperature for about 2 years were identified by the present immunoelectrosyneresis. The stains kept for a longer period could be detected with the anti-LSC consumption test. These results indicate that $\alpha_{2}$ macroglobulin lost its solubility in about 2 years and that the immunoreactivity was scarcely affected for several years.

In conclusion, anti-LSC serum is considered to be quite effective for differentiating species-specificity of blood stains in forensic practice.

\section{References}

1) Bauer, K. (1974) A study on the determinant structure of human serum albumin. J. Immunogenetics, 1, 315-321.

2) Cox, C.D. \& Vermillon, S.D. (1956) Preservation of sheep erythrocytes and their use in a rapid plate titration of heterophilic antibodies in infectious mononucleosis. J. Lab. clin. Med., 48, 298-303. 3) Dray, $\mathrm{S} .(1960)$ Three $\gamma$-globulins in normal human serum revealed by monkey
precipitins. Science, 132, 1313-1314. 
4) Gempel, J.A., Werder, A.A. \& Morgan, P. (1960) Analysis of human and monkey serum utilizing the Ouchterlony technic. J. Forensic Sci., 5, 110-120.

5) Gibson, D.M. (1977) Species specificity in the isoelectric spectra of immunoglobulin light chains. $J$. Immunol., 118, 409-411.

6) Harris, H. \& Robson, E.B. (1963) Precipitin reaction between extracts of seeds of Canavalia ensiformis (Jack bean) and normal and pathological serum proteins. Vox Sang., 8, 348-355.

7) Hirshfeld, J. (1960) Immunoelectrophoresis procedure and application to the study of group specific variation in sera. Science Tools, 7, 18-25.

8) Hjerten, S. (1959) Calcium phosphate chromatography of normal human serum and of electrophoretically isolated serum proteins. Biochem. Biophys. Acta, 31, 261-235.

9) James, K. (1965) A study of the alpha 2-macroglobulin homologues of various species. Immunology, 8, 55-61.

10) Kuwata, M. \& Ishimoto, G. (1976) Preparation and partial characterization of macaque to human serum proteins. Jap. J. Legal Med., 30, 293-298. (Japanese)

11) Mokashi, R.H. \& Madiwale, M.S. (1974) Isoenzym-Methoden zur Untersheidung von Menschen- und Affenblut. Arch. Kriminol., 153, 48-53.

12) Nakamura, S., Tanaka, K. \& Murakawa, S. (1960) Specific protein of legumes which reacts with animal proteins. Nature, 188, 144-145.

13) Novotny, J. \& Franek, F. (1972) Uniformity and species-specificitic features of the $\mathrm{N}$-terminal amino acid sequence of procine immunoglobulin chains. Eur. $J$. Biochem., 31, 277-289.

14) Saunders, R., Dyce, B.J., Vannier, W.E. \& Haverback, B.J. (1971) The separation of alpha-2 macroglobulin into five components with differing electrophoretic and enzyme-binding properties. J. Clin. Invest., 50, 2376-2383.

15) Sivaram. S., Bhatnagar, R.K., Bhandari, S.K. \& Sijher, J.S. (1975) Differentiation between stains of human blood and blood of monkey. Forensic Sci., 6, 145-152.

16) Stavitsky, A.B. (1954) Mieromethods for the study of proteins and antibodies. I. Procadure and ganeral application of hemagglutination and hemagglutination-inhibition reactions with tannic acid and protein-treated red blood cells. J. Immunol., 72, 360367.

17) Tsugawa, N., Ohya, I., Sawada, H. \& Yada, S. (1971) On the species identification of human sera with the use of monospecific anti-human serum precipitin. Reports of the National Research Institute of Police Science, 24, 1-9. (Japanese)

18) Willemot, J. \& Parry, G. (1970) Une nouvelle réaction colorée applicable au dosage photocolorimétrique de l'acide tannique. Ann. pharm. franc., 28, 391-395.

19) Zuckerkandl, E. (1965) The evolution of hemoglobin. Sci. Amer., 212, 110-118. 